Open Access at : http://jurnal.umt.ac.id/index.php/replik/article/view/1443

\title{
KENDALA PELAKSANAAN PEMBAYARAN KOMPENSASI PEMUTUSAN HUBUNGAN KERJA BERDASARKAN UU RI NO. 13 TAHUN 2003 TENTANG KETENAGAKERJAAN (Studi Kasus Pada PT Pelayaran Nasional Indonesia(Persero))
}

\author{
Dauman \\ Fakultas hukum Universitas Pamulang \\ Email: Daumanhebat@gmail.com
}

\begin{abstract}
Abstrak
Kata-kata Pemutusan Hubungan Kerja merupakan suatu mimpi buruk khususnya bagi pekerja/buruh, sehingga setiap pekerja/buruh harus mengupayakan untuk menghindari terjadinya pemutusan hubungan kerja yang tidak normal misalnya pekerja melakukan kesalahan, begitu juga pengusaha akan menjadikan permasalahan, minimal pembayaran kompensasi pemutusan hubungan kerja, bahkan bisa jadi sampai permasalahan hukum. Satu hal yang terpenting dari terjadinya pemutusan hubungan kerja adalah sejauhmana pekerja/buruh memperoleh hak-hak minimalnya, sebagaimana yang tercantum dalam pasal 156 ayat (1) UU RI No. 13 tahun 2003 tentang Ketenagakerjaan. Hasil penelitian ini menunjukkan bahwa pelaksanaan pembayaran kompensasi PHK yang dilaksanakan oleh kantor pusat PT PELNI belum sepenuhnya melaksanakan ketentuan Undang-Undang Republik Indonesia Nomor 13 Tahun 2003 Tentang Ketenagakerjaan, baik ketentuan maupun pelaksanaannya, Kantor pusat PT PELNI disamping berpedoman pada Undang-Undang Republik Indonesia Nomor 13 Tahun 2003 Tentang Ketenagakerjaan justru mayoritas masih menggunakan Undang-Undang Republik Indonesia Nomor 11 tahun 1992 tentang Dana Pensiun. Padahal dalam kedua Undang-Undang tersebut jelas berbeda dalam aturan masing-masing.
\end{abstract}

Kata Kunci: Kompensasi pesangon, pemutusan hubungan kerja, pekerja. 


\section{PENDAHULUAN}

Sejak Negara Republik Indonesia didirikan, bangsa Indonesia telah menyadari bahwa pekerjaan adalah merupakan kebutuhan yang azasi bagi setiap warga Negara, sehingga perlu ditetapkan dalam konstitusi Negara, sebagaimana diamanatkan dalam Undang-Undang Dasar Negara Republik Indonesia tahun 1945 pasal 27 ayat (2) yang menyatakan: tiap-tiap warga Negara berhak atas pekerjaan dan penghidupan yang layak bagi kemanusiaan. Selanjutnya juga ditegaskan kembali dalam amandemen Undang-Undang Dasar Negara Republik Indonesia tahun 1945 pasal 28d ayat (2): "Setiap orang berhak untuk bekerja serta mendapat imbalan dan perlakuan yang adil dan layak dalam hubungan kerja”.

Hal tersebut berimplikasi pada kewajiban Negara untuk memfasilitasi setiap warga Negara agar dapat memperoleh pekerjaan yang layak bagi kemanusiaan, oleh karena itu perlu perencanaan yang matang dalam bidang Ketenagakerjaan untuk mewujudkan kewajiban Negara tersebut. Sebagaimana telah diatur dalam UU RI No. 13 tahun 2003 tentang Ketenagakerjaan telah memberikan landasan yang kuat atas kedudukan dan peranan perencanaan, pengembangan, pembinaan dan pengakhiran tenaga kerja, sehingga meminimalkan perselisihan hubungan industrial yang mengakibatkan pertentangan antara pemberi kerja dengan pekerja, antara lain berupa perselisihan hak, kewajiban, kepentingan dan pemutusan hubungan kerja. ${ }^{1}$

Kehadiran UU RI No. 13 tahun 2003 tentang Ketenagakerjaan telah memberikan nuansa baru dalam khasanah hukum perburuhan/ Ketenagakerjaan di Indonesia yakni: ${ }^{2}$

Mensejajarkan istilah buruh/pekerja, istilah majikan diganti menjadi pengusaha atau pemeberi kerja; istilah ini sudah lama diupayakan untuk dirubah agar lebih sesuai dengan hubungan Industrial Pancasila.

Menggantikan istilah perjanjian perburuhan (labour agreement)/ Kesepakatan Kerja Bersama (KKB) dengan istilah Perjanjian Kerja Bersama (PKB) yang berupaya diganti dengan alasan bahwa perjanjian perburuhan berasal dari

\footnotetext{
${ }^{1}$ Adrian Sutedi, Hukum Perburuhan, Jakarta: Sinar Grafika, 2009, hal. 2

${ }^{2}$ Lalu Husni, Pengantar Hukum Ketenagakerjaan Indonesia, Jakarta: PT. Raja Grafindo Persada, 2007. Hal.13.
} 
Negara liberal yang seringkali dalam pembuatannya menimbulkan benturan kepentingan antara pihak buruh dan majikan.

Sesuai dengan perkembangan zaman memberikan kesetaraan antara pekerja pria dan wanita, khususnya untuk bekerja pada malam hari. Bagi buruh/pekerja wanita berdasarkan undang-undang ini tidak lagi dilarang untuk bekerja malam hari. Akan tetapi pengusaha diberikan rambu-rambu yang harus ditaati mengenai hal ini.

Memberikan sanksi yang memadai serta menggunakan batas minimum dan maksimum, sehingga lebih menjamin kepastian hukum dalam penegakaannya. Mengatur mengenai sanksi administratif mulai dari teguran, peringatan tertulis, pembatasan kegiatan usaha, pembekuan usaha, pembatalan persetujuan, pembatalan pendaftaran, penghentian sementara sebagian atau seluruh alat produksi, dan pencabutan izin usaha. Pada peraturan perundang-undangan sebelumnya sanksi ini tidak diatur, selain itu sebagai kompilasi dari ketentuan hukum ketenagakerjaan Indonesia, sehingga memudahkan para pihak yang berkepentingan (stakeholders) untuk mempelajarinya.

Dalam pelaksanaan pembangunan nasional, tenaga kerja mempunyai peranan penting sebagai pelaku dan tujuan pembangunan. Sesuai dengan peranan dan kedudukan tenaga kerja, diperlukan pembangunan Ketenagakerjaan untuk meningkatkan kualitas tenaga kerja dan peran sertanya dalam pembangunan, serta peningkatan perlindungan tenaga kerja dan keluarganya sesuai harkat martabat kemanusiaan. Perlindungan terhadap tenaga kerja dimaksudkan untuk menjamin hak-hak dasar pekerja/buruh dan menjamin hak-hak dasar pekerja/buruh dan menjamin kesamaan kesempatan, serta perlakuan tanpa diskriminasi atas dasar apapun untuk mewujudkan kesejahteraan pekerja/buruh dan keluarganya dengan tetap memperhatikan perkembangan kemajuan dunia usaha. ${ }^{3}$

Namun secara sosiologis pekerja/buruh dalam posisi yang lemah, karena bermodal tenaganya saja, seorang pekerja/buruh kadangkala terpaksa menerima hubungan kerja dengan pengusaha meskipun hubungan tersebut memberatkan pekerja/buruh sendiri, lebih-lebih sekarang dengan banyaknya tenaga kerja yang

\footnotetext{
${ }^{3}$ Rocky Marbun, Jangan Mau Di-PHK Begitu Saja, Jakarta: Visimedia, 2010 hal. 10
} 
membutuhkan pekerjaan yang tidak sebanding dengan lapangan pekerjaan yang tersedia. pekerja/buruh.

Oleh karena itu pemerintah dengan menetapkan peraturan perundangundangan, turut serta melindungi pihak yang lemah (pekerja/buruh) dari tindakan semena-mena pengusaha, sehingga menempatkannya pada kedudukan yang layak sesuai dengan harkat dan martabat manusia. Dengan demikian, pada hakekatnya hukum ketenagakerjaaan dengan semua peraturan perundang-undangan yang ada bertujuan untuk melaksanakan keadilan sosial dengan jalan memberikan perlindungan kepada pekerja/buruh terhadap kekuasaan pengusaha. ${ }^{4}$

Walaupun setinggi-tinggi jabatan yang diduduki, sebesar-besarnya gaji yang diterima dan semewah-mewahnya fasilitas yang dinikmati oleh pekerja/karyawan ujung-ujungnya juga pensiun ${ }^{5}$. Pekerja/buruh pada hakekatnya orang yang menjual jasa baik tenaga maupun fikiran kepada pemberi kerja/pengusaha, yang diawali dari sejak masuk kerja kemudian meniti karir dalam perusahaan tersebut, sehingga pada hakekatnya tidak selamanya seumur hidup menjadi pegawai, artinya setiap pekerja suka atau tidak suka, pengakhiran hubungan kerja adalah sesuatu hal yang wajar, dialami oleh pekerja/buruh karena terjadinya hubungan antara pemberi kerja (pengusaha) dengan pekerja/buruh, meskipun sebab-sebabnya dan caranya yang berbeda-beda. Misalnya: sudah waktunya memasuki masa pensiun, meninggal dunia, sakit berkepanjangan, perusahaan bangkrut, kontraknya sudah berakhir atau bahkan pekerja/buruh sendiri yang melakukan kesalahan.

Kata-kata Pemutusan Hubungan Kerja (PHK) merupakan suatu mimpi buruk khususnya bagi pekerja/buruh, sehingga setiap pekerja/buruh harus mengupayakan untuk menghindari terjadinya PHK yang tidak normal misalnya pekerja melakukan kesalahan, begitu juga pengusaha akan menjadikan permasalahan, minimal pembayaran kompensasi PHK, bahkan bisa jadi sampai permasalahan hukum. Satu hal yang terpenting dari terjadinya PHK adalah sejauhmana pekerja/buruh memperoleh hak-hak minimalnya sebagaimana yang tercantum dalam pasal 156 ayat (1) UU RI No. 13 tahun 2003 tentang

\footnotetext{
${ }^{4}$ Zaeni Asyhadie, Hukum Kerja (Hukum Ketenagakerjaan Bidang Hubungan Kerja), Jakarta: Rajawali Pers, 2008, hal. 18.

${ }^{5}$ Valentino Dinsi, Ketika Pensiun Tiba, Jakarta: LET’S GO Indonesia, 2006, Hal. 14.
} 
Ketenagakerjaan yaitu; uang pesangon, uang penghargaan masa kerja dan uang penggantian hak yang harus diterima.

Pada umumnya PHK biasanya berasal dari inisiatif atau dikakukan oleh pengusuha akan tetapi bisa juga atas keinginan dari pekerja yang bersangkutan. "Peristiwa pengakhiran hubungan kerja seringkali menimbulkan permasalahan yang tidak mudah terselesaikan baik mengenai pengakhiran hubungan itu sendiri maupun permasalahan utamnya yaitu akibat hukum dari pengakhiran hubungan kerja, adakalanya pekerja/buruh dapat menerima pengakhiran hubungan kerja yang dilakukan oleh pengusaha, namun terjadi juga yang tidak menyetujui terhadap kompensasi yang ditawarkan oleh pengusaha atau bisa sebaliknya pengusaha tidak bisa menerima kompensasi yang ditawarkan oleh pekerja." 6

Dengan terbitnya UU RI No. 13 tahun 2003 tentang Ketenagakerjaan yang telah mengatur tentang besaran jumlah kompensasi atas pemutusan hubungan kerja seharusnya setiap perusahaan wajib berpedoman ketentuan tersebut termasuk perusahaan Badan Usaha Milik Negara (BUMN). Akan tetapi dalam pelaksanaannya terdapat perusahaan BUMN masih mengacu pada peraturan Pegawai Negri Sipil (PNS) yang berpedoman pada UU RI No. 11 tahun 1992 tentang Dana Pensiun, dimana perusahaan BUMN yang selama ini telah membuat program Dana Pensiun tersendiri, hal ini juga dilaksanakan di PT. Pelayaran Nasional Indonesia (Persero) yaitu pembayaran pensiun berdasarkan penghasilan dasar pensiun (gaji pokok) maksimal $80 \%)^{7}$, tergantung masa kerja pekerja yang bersangkutan. Akan tetapi disisi lain perusahaan BUMN tersebut memberikan tambahan fasilitas jaminan kesehatan pada saat pensiun, sedangkan ketentuan UU RI No. 13 tahun 2003 tentang Ketenagakerjaan perhitungan pembayaran Uang kompensasi PHK perhitungan hanya berdasarkan uang Pesangon, Uang Penghargaan dan Uang Penggantian hak yang harus diterima, dihitung berdasarkan upah/gaji bruto (seluruh komponen penghasilan pekerja yang diterima setiap bulan) dan tidak ada kewajiban memberikan fasilitas kesehatan pada saat pensiun.

\footnotetext{
${ }^{6}$ Edy Sutrisno Sidabutar, Pedoman Penyelesaian PHK, Jakarta: Elpress, 2005 Hal. 2

${ }^{7}$ Peraturan Dana Pensiun Pelni, Jakarta: DP Pelni, 1996, Hal. 26.
} 


\section{PEMBAHASAN}

\section{A. Hukum Ketenagakerjaan}

Hukum Ketenagakerjaan sebelumnya menggunakan istilah hukum Perburuhan, setelah kemerdekaan hukum ketenegakerjaan di Indonesia diatur berdasarkan ketentuan Undang-Undang No. 14 tahun 1969 tentang Pokok-Pokok Ketentuan Tenaga Kerja. Selanjutnya Undang-Undang tersebut dirasakan sudah tidak sesuai dengan perkembangan, sehingga pada tahun 1997 diterbitkan UndangUndang sebagai penggantinya yaitu Undang-Undang No. 25 tahun 1997 tentang Ketenagakerjaan. Lahirnya Undang-Undang No. 25 tahun 1997 tersebut menimbulkan beberapa protes dari masyarakat perburuhan, yang menimbulkan pro dan kontra akbatnya untuk sementara Undang-Undang No. 25 tahun 1997 tersebut ditangguhkan.

Setelah melalui beberapa perbaikan dan masukan dari para ahli di bidang Ketegakerjaaan dan para aktifis pekerja/buruh, akhirnya pada tahun 2003 ditetapakan Undang-Undang No. 13 tahun 2003 tentang Ketenagakerjaan (Lembaran Negara Tahun 2003, Nomor: 39, Tamabahan Lembaran Negara Tahun 2003 Nomor 4279). Selanjuntya disingkat dengan UU No. 13 tahun 2003. Hukum Ketenagakerjaan yang sebelumnya disebut hukum perburuhan merupakan terjemahan dari arbeidsrechts. Terdapat beberapa pendapat atau batasan pengertian dari hukum perburuhan. Mr. A. H. Molenaar memberikan batasan penegertian perburuhan dari arbeidsrechts adalah bagian dari hukum yang berlaku yang pada pokoknya mengatur hubungan antara buruh dan majikan, antara buruh dengan buruh dan antara buruh dengan penguasa. Sedangkan menurut Mr. M. G. Levenbach arbeidsrechts adalah sebagai suatu yang meliputi hukum yang yang berkenaan dengan hubungan kerja, dimana pekerjaan itu dilakukan dibawah pimpinan dan dengan keadaan penghidupan yang langsung bersangkut paut dengan hubungan kerja itu. ${ }^{8}$ Adapun Imam Supomo memberikan batasan pengertian Hukum Perburuhan adalah suatu himpunan peraturan, baik tertulis maupun tidak tertulis yang berkenaan dengan kejadian dimana seorang bekerja pada orang orang lain dengan menerima upah. ${ }^{9}$

Pengertian hukum perburuhan mengandung 3 unsur, sebagai berikut:

\footnotetext{
${ }^{8}$ Iman Soepomo, Pengantar Hukum Perburuhan, Jakarta: Djambatan, 1987. Hal. 1

${ }^{9}$ Ibid. Hal. 3.
} 
1. Adanya peraturan

2. Bekerja pada orang lain

3. Upah

Peraturan mencakup aturan hukum yang tertulis dan tidak terulis. Hukum yang tertulis meliputi seluruh perundang-undangan berdasarkan jenis dan hirarki peraturan perundang-undangan, ${ }^{10}$ sebagaimana yang diatur dalam Undang-Undang No. 12 Tahun 2011 tentang Pembentukan Peraturan Perundang-Undangan, Yaitu:

1. Undang-Undang Dasar Negara Republik Indonesia Tahun 1945;

2. Ketetapan Majelis Permusyawaratan Rakyat;

3. Undang-Undang/Peraturan Pemerintah Pengganti Undang-Undang;

4. Peraturan Pemerintah;

5. Peraturan Presiden;

6. Peraturan Daerah Provinsi; dan

7. Peraturan Daerah Kabupaten/Kota.

Sementara itu yang dimaksud dengan hukum yang tidak tertulis, misalnya hukum kebiasan, etika dan nilai-nilai moral.

Pada saat ini istilah Hukum Perburuhan semakin tidak populer dengan diundangkannya Undang-Undang No. 13 tentang Ketenagakerjaan tersebut, yang menjadi payung hukum bagi masalah-masalah yang terkait dengan permasalahan Ketenagakerjaan.

Sejalan dengan diundangkannya UU No. 13 tahun 2003 tentang Ketenagakerjaan, dengan demikian mengubah istilah dalam ketentuan perundangundangan semula Perburuhan menjadi Ketenagakerjaan. Perburuhan berasal dari kata "buruh", yang secara etimologis dapat diartikan dengan keadaan memburuh, yaitu keadaan dimana seorang buruh bekerja pada orang lain (pengusaha). Sedangkan Ketenagakerjaan berasal dari kata dasar "tenaga kerja" yang artinya "segala hal yang berhubungan dengan tenaga kerja pada waktu sebelum, selama, dan sesudah masa kerja (Pasal 1 huruf I UU. No. 13 tahun 2003 tentang Ketenagakerjaan). ${ }^{11}$

\footnotetext{
${ }^{10}$ Asri Wijayanti, Hukum Ketenagakerjaan Pasca Reformasi, Jakarta: Sinar Grafika, 2010. Hal. 4

${ }^{11}$ Zaeni Asyhadie, Op. Cit, hal. 1.
} 
Dengan demikian dapat disimpulkan bahwa istilah Perburuhan mengandung makna yang lebih sempit cakupannya yaitu terbatas pada waktu buruh bekerja pada pengusaha saja, sedangkan Ketenagakerjaan mengandung pengertian yang lebih luas yaitu hubungan pekerja sebelum bekerja, pada saat bekerja dan penyelesaian setelah mengakhiri hubungan kerjanya. Disamping itu, subjek yang diatur dalam hukum perburuhan adalah hanya buruh saja, yaitu "orang yang bekerja pada pihak lain dengan menerima upah" tersebut, sedangkan subjek dan objek hukum Ketenagakerjaan mengandung cakupan lebih luas yaitu termasuk kaitan dengan keluarga pekerja. ${ }^{12}$

Dari pengertian ini dapat dipahami bahwa yang di atur dalam hukum Ketenagakerjaan adalah segala hal peraturan yang berkaitan dengan pekerja/buruh baik itu menyangkut hal-hal yang ada sebelum masa kerja (preemployment) antara lain menyangkut pemagangan, kewajiban mengumumkan lowongan kerja, dan lainlain. Hal-hal yang berkenaan selama masa bekerja (duringemployment) antara lain menyangkut perlindungan kerja: upah, jaminan sosial, kesehatan dan keselamatan kerja, pengawasan kerja, serta hal-hal lain sesudah masa kerja antara lain pesangon, dan pensiun/jaminan hari tua.

\section{B. Kesejahteraan Pekerja/Buruh}

Problematika Ketenagakerjaan sepanjang masa tidak pernah selesai khusunya permasalahan kesejahteraan yang berhubungan dengan pekerja/buruh. Hal ini lebih diakibatkan kelemahan pemerintah secara sistematik dalam mengimplementasikan undang-undang Ketenagakerjaan, bahkan terdapat adanya kecenderungan penyimpangan, hal lain masalah koordinasi dan kinerja antar lembaga pemerintah belum optimal dan masih sangat memprihatinkan. ${ }^{13}$

Adapun bebarapa kesejahteraan pekerja/buruh yang telah ditetapkan UndangUndang Ketenagakerjaan antara lain:

\section{Hak Upah}

Hak Upah pekerja/buruh sebagai salah satu aspek penting yang harus dilindungi, sebagaimana diamanatkan dalam Undang-Undang No. 13 tahun 2003 tentang Ketenagakerjaan pasal 88, bahwa: Setiap pekerja/buruh berhak memperoleh penghasilan yang memenuhi penghidupan yang layak bagi

\footnotetext{
${ }^{12}$ Ibid, hal. 2.

${ }^{13}$ Adrian Sutedi, Hukum Perburuhan, Jakarta: Sinar Grafika, 2009. Hal 142
} 
kemanusiaan. Maksud dari penghidupan yang layak, dimana jumlah penghasilan pekerja/buruh dari hasil pkerjaannya mampu memenuhi kebutuhan hidup pekerja/buruh dan keluarganya secara wajar, yang meliputi makana dan minuman, sandang, perumahan, pendidikan, kesehatan, rekreasi, dan jaminan hari tua. ${ }^{14}$ Manusia dalam hidupnya selau berusaha untuk memenuhi segala kebutuhannya. Kebutuhan hidup sangatlah bervariasi, sedikit atau banyaknya adalah relatif tergantung pada kemampuan atau daya beli seseorang. Daya beli seseorang tentulah sangat dipengaruhi oleh penghasilan yang ia peroleh pada saat bekerja. ${ }^{15}$

Berdasarkan Undang-Undang No. 13 tahun 2003 tentang Ketenagakerjaan pasal 1 angka 30 bahwa: pengertian upah adalah hak pekerja/buruh yang diterima dan dinyatakan dalam bentuk uang sebagai imbalan dari pengusaha atau pemberi kerja kepada pekerja/buruh yang ditetapkan dan dibayarkan menurut suatu perjanjian kerja, kesepakatan, atau peraturan perundang undangan, termasuk tunjangan bagi pekerja/buruh dan keluarganya atas suatu pekerjaan dan/atau jasa yang telah atau akan dilakukan.

Untuk maksud tersebut pemerintah menetapkan kebijakan pengupahan untuk melindungi pekerja/buruh sebagaimana diamanatkan dalam UndangUndang No. 13 tahun 2003 tentang Ketenagakerjaan pasal 88 ayat (1), yang meliputi:

a) upah minimum;

b) upah kerja lembur;

c) upah tidak masuk kerja karena berhalangan;

d) upah tidak masuk kerja karena melakukan kegiatan lain di luar pekerjaannya;

e) upah karena menjalankan hak waktu istirahat kerjanya;

f) bentuk dan cara pembayaran upah;

g) denda dan potongan upah;

h) hal-hal yang dapat diperhitungkan dengan upah;

i) struktur dan skala pengupahan yang proporsional;

j) upah untuk pembayaran pesangon; dan

\footnotetext{
${ }^{14}$ Abdul Khakim, Op. Cit., Hal. 130.

${ }^{15}$ Asri Wijayanti, Op Cit., Hal. 102
} 
k) upah untuk perhitungan pajak penghasilan.

Upah minimum sebagaimana dimaksudkan di atas diarahkan kepada pencapaian kebutuhan hidup. Pengusaha dilarang membayar upah lebih rendah dari upah minimum. Pengaturan pengupahan yang ditetapkan atas kesepakatan antara pengusaha dengan pekerja/buruh atau serikat pekerja/serikat buruh tidak boleh rendah dari ketentuan pengupahan yang ditetapkan peraturan perundangundangan yang berlaku. Dalam hal kesepakatan tersebut lebih rendah atau bertentangan dengan peraturan perundang-undangan, kesepakatan tersebut batal demi hukum, dan pengusaha wajib membayar selisih kekurangannya pembayarannya tersebut. ${ }^{16}$

Dengan demikian adanya upah yang diterima pekerja/buruh sebagai akibat dari pekerjaan yang telah dilakukan, oleh sebab itu apabila pengusaha memberikan upah yang layak sebagaimana telah diamanatkan undang-undang Ketenagakerjaan tersebut, sangat dimungkinkan mengurangi perselisihan antara pekerja/buruh dengan penguasa.

Apabila diperhatikan pasal 150 , badan usaha yang mempekerjakan tenaga kerja dan membayar upah atau imbalan dalam bentuk lain, seharusnya mengikuti ketentuan PHK. Sebagaimana disebut dalam UU Ketengakerjaan 2003, mereka itu sebagai berikut;

a) Badan usaha berbentuk hukum.

b) Badan usaha yang tidak berbentuk badan hukum.

c) Badan usaha swasta.

d) Badan usaha milik Negara.

e) Badan-badan sosial dan badan usaha lainnya yang memiliki pengurus dan mempekerjakan orang lain dengan membayar upah atau imbalan dalam bentuk lain.

Dengan demikian semua badan usaha seharusnya berpedoman pada UU No. 13 tahun 2003 tentang Ketenagakarjaan sebagai acuan jika melaksanakan pemutusan hubungan kerja. ${ }^{17}$ Sehubungan dampak PHK sangat kompleks dan cenderung menimbulkan permasalahan hukum, maka mekanisme dan prosedur

\footnotetext{
${ }^{16}$ Lalu Husni, Op. Cit. Hal. 150.

${ }^{17}$ Ibid. hal. 77
} 
PHK diatur sedimikian rupa agar pekerja/buruh tetap mendapatkan perlindungan yang layak dan memperoleh hak-haknya sesuai keyentuan perundang-undangan yang berlaku. ${ }^{18}$

Oleh karena itu apabila terpaksa harus dilaksanakan PHK Pengusaha wajib memberikan sejumlah kompensasi kepada pekerja/buruh sebagaimana ketentuan dalam UU No. 13 tahun 2003 tentang Ketenagakerjaan pasal 156 bahwa: Dalam hal terjadi pemutusan hubungan kerja, pengusaha diwajibkan membayar uang pesangon dan atau uang penghargaan masa kerja dan uang penggantian hak yang seharusnya diterima.

Sebagaimana ditetapkan dalam Undang-Undang No. 13 tahun 2003 tentang Ketenagakerjaan, bahwa pemberi kerja/pengusaha diwajibkan memberikan sejumlah kompensi PHK pada saat melakukan PHK terhadap pekerja/buruh, Jumlah kompensasi PHK secara umum yang harus dibayarkan oleh pengusaha apabila terjadi PHK berdasar pasal 156 ayat (1) pengusaha diwajibkan membayar uang pesangon dan atau uang penghargaan masa kerja dan uang penggantian hak yang seharusnya diterima. Berdasarkan ketentuan tersebut secara rinci perhitungannnya adalah sebagai berikut:

a) Perhitungan uang pesangon (pasal 156 ayat (2) UU Ketenagakerjaan) paling sedikit sebagai berikut :

1) masa kerja kurang dari 1 (satu) tahun, 1 (satu) bulan upah;

2) masa kerja 1 (satu) tahun atau lebih tetapi kurang dari 2 (dua) tahun, 2 (dua) bulan upah;

3) masa kerja 2 (dua) tahun atau lebih tetapi kurang dari 3 (tiga) tahun, 3 (tiga) bulan upah;

4) masa kerja 3 (tiga) tahun atau lebih tetapi kurang dari 4 (empat) tahun, 4 (empat) bulan upah;

5) masa kerja 4 (empat) tahun atau lebih tetapi kurang dari 5 (lima) tahun, 5 (lima) bulan upah;

6) masa kerja 5 (lima) tahun atau lebih, tetapi kurang dari 6 (enam) tahun, 6 (enam) bulan upah;

\footnotetext{
${ }^{18}$ Abdul Khakim, Op Cit. Hal.185.
} 
7) masa kerja 6 (enam) tahun atau lebih tetapi kurang dari 7 (tujuh) tahun, 7 (tujuh) bulan upah.

8) masa kerja 7 (tujuh) tahun atau lebih tetapi kurang dari 8 (delapan) tahun, 8 (delapan) bulan upah;

9) masa kerja 8 (delapan) tahun atau lebih, 9 (sembilan) bulan upah.

b) Perhitungan uang penghargaan masa kerja (pasal 156 ayat (3) UU Ketenagakerjaan) paling sedikit sebagai berikut :

1) masa kerja 3 (tiga) tahun atau lebih tetapi kurang dari 6 (enam) tahun, 2 (dua) bulan upah;

2) masa kerja 6 (enam) tahun atau lebih tetapi kurang dari 9 (sembilan) tahun, 3 (tiga) bulan upah;

3) masa kerja 9 (sembilan) tahun atau lebih tetapi kurang dari 12 (dua belas) tahun, 4 (empat) bulan upah;

4) masa kerja 12 (dua belas) tahun atau lebih tetapi kurang dari 15 (lima belas) tahun, 5 (lima) bulan upah;

5) masa kerja 15 (lima belas) tahun atau lebih tetapi kurang dari 18 (delapan belas) tahun, 6 (enam) bulan upah;

6) masa kerja 18 (delapan belas) tahun atau lebih tetapi kurang dari 21 (dua puluh satu) tahun, 7 (tujuh) bulan upah;

7) masa kerja 21 (dua puluh satu) tahun atau lebih tetapi kurang dari 24 (dua puluh empat) tahun, 8 (delapan) bulan upah;

8) masa kerja 24 (dua puluh empat) tahun atau lebih, 10 (sepuluh ) bulan upah.

c) Uang penggantian hak yang seharusnya diterima (pasal 156 ayat (4) UU Ketenagakerjaan) paling sedikit meliputi :

1) cuti tahunan yang belum diambil dan belum gugur;

2) biaya atau ongkos pulang untuk pekerja/buruh dan keluarganya ketempat dimana pekerja/buruh diterima bekerja;

3) penggantian perumahan serta pengobatan dan perawatan ditetapkan $15 \%$ (lima belas perseratus) dari uang pesangon dan/atau uang penghargaan masa kerja bagi yang memenuhi syarat;

4) hal-hal lain yang ditetapkan dalam perjanjian kerja, peraturan perusahaan atau perjanjian kerja bersama. 
Komponen upah yang digunakan sebagai dasar perhitungan uang pesangon, uang penghargaan masa kerja, dan uang pengganti hak yang seharusnya diterima berdasarakan Undang-Undang No. 13 tahun 2003 tentang Ketenagakerjaan pasal 157, adalah sebagai berikut:

a) Upah pokok;

b) Segala macam bentuk tunjangan yang bersifat tetap yang diberikan kepada pekerja/buruh dan keluarganya, termasuk harga pembelian dari catu yang diberikan kepada pekerja/buruh secara cuma-cuma, yang apabila catu harus dibayar pekerja/buruh dengan subsidi, maka sebagai upah dianggap selisih antara harga pembelian dengan harga yang harus dibayar oleh pekerja/buruh.

c) Dalam hal penghasilan pekerja/buruh dibayarkan atas dasar perhitungan harian, maka penghasilan sebulan adalah sama dengan 30 kali penghasilan sehari.

d) Dalam hal upah pekerja/buruh dibayarkan atas dasar perhitungan satuan hasil, potongan/borongan atau komisi, maka penghasilan sehari adalah sama dengan pendapatan rata-rata per hari selama 12 (dua belas) bulan terakhir, dengan ketentuan tidak boleh kurang dari ketentuan upah minimum provinsi atau kabupaten/kota.

e) Dalam hal pekerjaan tergantung pada keadaan cuaca dan upahnya didasarkan pada upah borongan, maka perhitungan upah sebulan dihitung dari upah rata-rata 12 (dua belas) bulan terakhir.

\section{Sanksi Hukum bagi Pengusaha yang Melanggar UU RI No. 13 tahun 2003 tentang Ketenagakerjaan}

Dalam rangka mengoptimal suatu peraturan sehingga dilaksanakan dengan baik, setiap peraturan perlu diberikan sanksi bagi yang melanggarnya. Sejalan hal tersebut Undang-Undang Nomor 13 tahun 2003 tentang Ketenagakerjaan juga memuat ketentuan pidana bagi pihak yang melanggarnya. Dalam undang-undang tersebut ditunjuk pegawai atau badan yang berwenang dan berkompeten dalam melakukan penyidikan.

Sebagaimana diatur dalam Undang-Undang Nomor 13 tahun 2003 pasal 182 memberikan wewenang kepada pejabat polisi Negara Republik Indonesia dan 
pegawai pengawas Ketenagakerjaan selaku penyidik pegawai negeri sipil (PPNS) sesuai dengan peraturan perundang-undangan yang berlaku untuk melaksanakan hal-hal sebagai berikut:

1. Melakukan pemeriksaan atas kebenaran laporan serta keterangan tentang tindak pidana di bidang ketenaga-kerjaan;

2. Melakukan pemeriksaan terhadap orang yang diduga melakukan tindak pidana di bidang ketenagakerjaan

3. Meminta keterangan dan bahan bukti dari orang atau badan hukum sehubungan dengan tindak pidana di bidang ketenagakerjaan;

4. Melakukan pemeriksaan atau penyitaan bahan atau barang bukti dalam perkara tindak pidana di bidang ketenagakerjaan;

5. Melakukan pemeriksaan atas surat dan/atau dokumen lain tentang tindak pidana di bidang ketenagakerjaan;

6. Meminta bantuan tenaga ahli dalam rangka pelaksanaan tugas penyidikan tindak pidana di bidang ketenagakerjaan; dan

7. Menghentikan penyidikan apabila tidak terdapat cukup bukti yang membuktikan tentang adanya tindak pidana di bidang ketenagakerjaan.

Adapun ketentuan-ketentuan pidana yang disebutkan dalam beberapa pasal sebagaimana yang termuat pada Undang-Undang Nomor 13 tahun 2003 tentang Ketenagakerjaan adalah sebagai berikut: ${ }^{19}$

1. Menurut ketentuan pasal 183 UU Nomor 13 tahun 2003 tentang Ketenagakerjaan pengusaha dilarang memepekerjakan dan melibatkan anak pada pekerjaan-pekerjaan terburuk, misalnya perbudakan, pelacuran, produksi pornografi, pertunjukan porno, atau perjudian, serta memanfaatkan, menyediakan, atau melibatkan anak untuk produksi dan perdagangan minuman keras, narkotika, psikotropika, dan zat adiktif lainnya dan semua pekerjaan yang membahayakan kesehatan, keselamatan, atau moral anak. Terhadap pelanggaran ini pengusaha diancam dengan pidana penjara paling lama 5 (lima) tahun dan/atau denda paling sedikit Rp. 200.000.000.- dan paling banyak Rp. 500.000.000.-.

\footnotetext{
${ }^{19}$ Rocky Marbun, Op Cit. Hal. 132
} 
2. Menurut ketentuan pasal 184 UU Nomor 13 tahun 2003 tentang Ketenagakerjaan pengusaha wajib mengikutsertakan pekerja pada program pensiun. Jika kewajiban tersebut tidak dipenuhi, sesuai dengan ketentuan dalam pasal 167 ayat (5) pengusaha wajib memberikan kepada pekerja/buruh uang pesangon sebesar dua kali ketentuan pasal 156 ayat (2), uang penghargaan masa kerja satu kali ketentuan pasal 156 ayat (3), dan uang penggantian hak sesuai ketentuan pasal 156 ayat (4). Jika tidak juga memenuhi kewajiban tersebut, pengusaha akan dikenakan sanksi pidana penjara paling singkat satu tahun dan/atau denda paling sedikit Rp. 100.000.000.- dan paling banyak Rp. 500.000.000.--

3. Menurut ketentuan pasal 185 UU Nomor 13 tahun 2003 tentang Ketenagakerjaan pengusaha harus memenuhi ketentuan yang tercantum dalam pasal 42 tentang penggunaan tenaga asing, pasal 68 tentang larangan mempekerjakan anak cacat,; pasal 69 ayat (2) tentang kewajiban pengusaha memberikan kesempatan yang secukupnya kepada pekerja/buruh untuk melaksanakanibadah yang diwajibkan oleh agamanya; pasal 82 tentang kewajiban pengusaha memberikan libur bagi wanita yang melahirkan dan yang keguguran kandungannya; pasal 90 ayat (1) tentang pengusaha dilarang membayar upah lebih rendah dari pada upah minimum; pasal 143 tentang larangan menghalangi dan menangkap, serta menahan pekerja yang menggunakan hak mogoknya; dan pasal 160 ayat (4) dan ayat (7) tentang pengusaha wajib mempekerjakan pekerja/buruh kembali bila telah diputuskan tidak bersalah oleh pengadilan dalam perkara pidana dan kewajiban membayar kepada pekerja/buruh yang mengalami pemutusan hubungan kerja. Jika pengusaha melanggar, akan dikenakan sanksi pidana penjara paling singkat satu tahun dan paling lama empat tahun dan/atau denda paling sedikit Rp. 100.000.000.- dan paling banyak Rp. 400.000.000.-.

4. Menurut ketentuan pasal 186 UU Nomor 13 tahun 2003 tentang Ketenagakerjaan pengusaha harus memenuhi ketentuan yang terdapat dalam pasal 35 ayat (2) dan ayat (3) tentang kewajiban memberikan perlindungan yang mencakup kesejahteraan, keselamatan, dan kesehatan baik mental maupun fisik tenaga kerja; pasal 93 ayat (2) tentang pengusaha 
wajib membayar upah jika buruh sakit, menikah, jika ada keluarga yang meninggal, menjalankan ibadah agamanya, menjalankan kewajiban Negara, menjalankan kewajiban sebagai anggota serikat pekerja/buruh, dan menjalankan pendidikan dari perusahaan; pasal 137 tentang mogok kerja sebagai hak dasar pekerja/buruh dan serikat pekerja/serikat buruh dilakuakn secara sah, tertib, dan damai sebagai akibat gagalnya perundingan; dan pasal 138 ayat (1) tentang pekerja/buruh dan/atau serikatpekerja/serikat buruh lain untuk mogok kerja pada saat mogok kerja berlangsung dilakukan dengan tidak melanggar hukum. Jika pengusaha melanggar, akan dikenakan sanksi pidana penjara paling singkat satu tahun dan paling lama empat tahun dan/atau denda paling sedikit Rp. 100.000.000.- dan paling banyak Rp. 400.000.000.-.

5. Menurut ketentuan pasal 187 UU Nomor 13 tahun 2003 tentang Ketenagakerjaan pengusaha harus memenuhi ketentuan yang tercantum dalam pasal 137 ayat (2) tentang lembaga penempatan tenaga kerja swasta wajib memiliki izin tertulis menteri atau pejabat yang ditunjuk; pasal 44 ayat (1) tentang pemberi kerja tenaga kerja asing wajib menaati ketentuan mengenai jabatan dan standar kompetensi yang berlaku; pasal 45 ayat (1) tentang pemberi kerja tenaga kerja asing yang dipekerjakan untuk alih teknologi dan alih keahlian dari tenaga kerja asing; pasal 167 ayat (1) tentang pengusaha yang yang mempekerjakan tenga kerja penyandang cacat wajib memberikan perlindungan sesuai dengan jenis dan derajat kecacatannya; pasal 71 ayat (2) tentang pengusaha yang mempekerjakan anak harus memenuhi syarat; pasal 76 tentang kewajiban memberikan perlindungan bagi pekerja wanita; pasal 78 ayat (2) tentang pengusaha yang mempekerjakan pekerja/buruh melebihi waktu kerja wajib membayar upah kerja lembur; pasal 79 ayat (1) dan ayat (2) tentang pengusaha wajib member waktu istirahat dan cuti kepada pekerja/buruh; pasal 85 ayat (3) tentang pengusaha yang mempekerjakan pekerja/buruh yang melakukan pekerjaan pada hari libur resmi wajib membayar upah kerja lembur; dan pasal 144 tentang pengusaha dilarang mengganti pekerja/buruh lain dari luar perusahaan dan memberikan sanksi atau tindakan balasan dalam bentuk apapun kepada pekerja/buruh dan pengurus serikat pkerja/serikat buruh 
selama dan sesudah melakukan mogok kerja. Jika pengusaha melanggar akan dikenakan sanksi pidana kurungan paling singkat satu bulan paling lama 12 bulan dan/atau denda paling sedikit Rp. 10.000.000.- dan paling banyak Rp. 100.000.000.-.

6. Menurut ketentuan pasal 188 UU Nomor 13 tahun 2003 tentang Ketenagakerjaan pengusaha harus mematuhi ketentuan yang terdapat dalam pasal 14 ayat (2) tentang lembaga pelatihan kerja swasta wajib memperoleh izin atau mendaftar ke instansi yang bertanggung jawab di bidang Ketenagakerjaan di Kabupaten/kota; pasal 38 ayat (2) tentang lembaga penempatan tenaga kerja swasta hanya dapat memungut biaya penempatan tenaga kerja dari pengguna tenaga kerja dan dari tenaga kerja golongan dan jabatan tertentu ; pasal 68 ayat (1) tentang dalm hal perjanjian kerja waktu tidak tertentu dibuat secara lisan, pengusaha wajib membuat surat pengangkatan bagi pekerja/buruh yang bersangkutan; pasal 78 ayat (1) tentang pengusaha yang mempekerjakan pekerja/buruh melebihi waktu kerja harus memenuhi syarat, yaitu persetujuan pekerja; pasal 108 ayat (1) tentang pengusaha yang mempekerjakan pekerja/buruh sekurang-kurangnya 10 orang wajib membuat peraturan perusahaan; pasal 111 ayat (3) tentang wajib memperbaharui peraturan perusahaan setelah dua tahun; pasal 114 tentang pengusaha wajib memberitahukan dan menjelaskan isi dan memberikan naskah peraturan perusahaan atau perubahannya kepada pekerja/buruh; serta pasal 148 tentang pengusaha wajib memberitahukan secara tertulis kepada pekerja/buruh dan/atau serikat pekerja/serikat buruh, serta instansi yang bertanggung jawab di bidang ketenagakerjaan setempat sekurang-kurangnya tujuh hari kerja sebelum penutupan perusahaan (lock out) dilaksnakan. Jika pengusaha melanggar, akan dikenakan sanksi pidana denda paling sedikit Rp. 5.000.000.- dan paling banyak Rp. 50.000.000.-.

7. Menurut ketentuan pasal 189 UU Nomor 13 tahun 2003 tentang Ketenagakerjaan yang menyatakan walaupun pengusaha telah dikenakan sanksi pidana baik penjara maupun kurungan dan/atau denda, kewajiban terhadap yang telah ditentukan tetap wajib dijalankan atau tidak hilang dengan sendirinya. Ketentuan dalam pasal ini merupakan jaminan atas hak- 
hak pekerja atas kesejahteraannya jika pengusha melakukan pelanggaran, baik pidana maupun perdata.

Dengan demikian pemerintah sebagai wasit telah memberikan ramburambu yang sangat tegas dan rinci kepada pemberi kerja/pengusaha agar menaati kewajiban ketentuan peraturan perundang-undangan tersebut, sehingga hak-hak pekerja/buruh yang dipandang pada posisi yang lemah dapat dipenuhi. Apabila pemberi kerja/pengusaha telah melaksanakan ketentuan tersebut, yang merupakan hak-hak minimal pekerja/buruh, maka hampir dapat dipastikan tidak akan terjadi permasalahan hukum antara pemberi kerja/pengusaha dan pekerja/buruh, sehingga pengusaha dapat tenang dalam mengembangkan usahanya sementara pekerja/buruh juga tenang dalam melaksanakan tugasnya yang bermuara akan menguntungkan pada kedua belah pihak, baik pemeberi kerja/pengusaha maupun pekerja/buruh, yang mana perusahaan akan mencapai kemajuan dan pekerja/buruh akan menikmati kesejahteraan secara optimal.

\section{Pelaksanaan Pembayaran Kompensasi PHK di PT. Pelni}

Dalam rangka mempersiapkan terjadinya pemutusan hubungan kerja terhadap para pekerjanya, Direksi PT PELNI (sebagai pemberi kerja) telah mempersiapkan program kesejahteraan untuk para pekerja khususnya pada saat memasuki usia pensiun atau meninggal dunia/cacat seumur hidup. Direksi PT PELNI mendirikan badan hukum dalam bentuk Yayasan Dana Pensiun PELNI, pada tanggal 1 April 1974 berdasarkan akte Notaris Bebasa Daeng Lalo No. 1 tanggal 1 April 19874, selanjutnya dengan lahirnya Undang-Undang No. 11 tahun 1992 tentang Dana Pensiun, maka Yayasan disesuaikan dengan Undang-Undang tersebut, yang diberikan nama "Dana Pensiun PELNI" sesuai SK Direksi PT PELNI Nomor 17/HKO/DIR/II/2003 tanggal 10 Februari 2003 yang telah disahkan oleh Menteri Keuangan dengan Nomor Surat KEP-073/KM.6/2003 tanggal 4 Maret 2003. ${ }^{20}$ Pendiri (PT PELNI) bertanggung jawab atas kecukupan dana untuk memenuhi kewajiban membayar manfaat pensiun kepada peserta atau pihak-pihak

\footnotetext{
${ }^{20}$ Peraturan Dana Pensiun PT. Pelni, Jakarta: Dapen Pelni, 2006. Hal. 1
} 
yang berhak atas manfaat pensiun tersebut, karena Dana Pensiun PELNI memberikan manfaat pensiun berpedoman yaitu "manfaat pasti" artinya para pensiunan PELNI akan menerima manfaat pensiun secara pasti yaitu sebesar maksimal $80 \%$. (delapan puluh prosen) dari gaji pokok. Sejak berlakunya Undang-Undang Republik Indonesia No. 11 tahun 1992 tentang Dana Pensiun tersebut, bahwa lembaga Dana Pensiun tersebut hanya boleh mengelola khusus pembayaran pensiunan, maka Direksi PT PELNI mendirikan badan hukum tersendiri dengan nama Yayasan Kesehatan Pensiunan PELNI (selanjutnya disingkat YKPP), secara khusus fungsinya adalah memberikan jaminan pelayanan kesehatan kepada para pensiunan pelni dan istri.

Dalam melaksanakan pembayaran pengupahan di PT PELNI pada prinsipnya menggunakan sistim balas jasa (merit sytem) akan tetapi disisi lain masih menggunakan standar gaji pokok, dimana tujuannya adalah memberikan kesempatan pada pekerja untuk berlomba-lomba dalam meraih prestasi. Pada pokoknya PT PELNI menerapkan manajemen sumber daya manusia berdasarkan merit sytem tersebut, dimaksudkan memberikan penghargaan/hadiah (reward) pada pekerja yang berprestasi atau memberikan kontribusi banyak bagi perusahaan, sebaliknya akan memberikan hukuman/sanksi (punishment) bagi pekerja yang terbukti merugikan perusahaan.

Adapun komponen upah pekerja di PT PELNI, terdiri dari sebagai berikut: ${ }^{21}$

1. Gaji Pokok

2. Tunjangan Istri (10\% dari gaji pokok pekerja)

3. Tunjangan Anak (5\% peranak dari gaji pokok pekerja)

4. Tunjangan Penyesuaian (sesuai klas jabatan)

5. Insentif Prestasi (sesuai klas jabatan)

Dari komponen upah tersebut yang merupakan upah tetap adalah Gaji Pokok, Tunjangan Istri, Tunjangan Anak dan Tunjangan Penyesuaian, sedangkan Insentif Prestasi bersifat tidak tetap, artinya apabila pekerja tidak memberikan prestasi berarti tidak memperoleh insentif, paling tidak apabila prestasi tidak maksimal maka insentifnya akan dikurangi, misalnya terlambat masuk kerja atau

\footnotetext{
${ }^{21}$ Ibid. Hal. 24
} 
lebih cepat pulang kerja akan dipotong Insentif Prestasinya tersebut, kecuali memperoleh ijin dari pimpinan unit kerjanya. Jadi apabila hari itu tidak masuk kerja tanpa alasan yang tidak bisa dipertanggung-jawabkan, maka pada hari tersebut tidak diberikan Insentif Prestasi.

Sedangkan sebagai dasar perhitungan dalam pembayaran pensiun bagi pekerja yang menjalani pensiun adalah diperhitungkan hanya dari gaji pokok terakhir, dikalikan masa kerja maksimal dihitung 32 tahun, akan tetapi apabila masa kerja kurang dari 32 tahun dihitung secara proporsional. Adapun perhitungan pertahun masa kerja adalah $2.5 \%$, sehingga pensiunan pelni hanya memperoleh maksimal $80 \%$ dari gaji pokok terakhir tersebut.

Secara umum dapat digambarkan bahwa perusahaan BUMN tersebut tidak melaksanakan ketentuan pemberian kompensasi PHK, sebagaimana yang telah ditetapkan dalam Undang-Undang No. 13 tahun 2013 tentang Ketenagakerjaan, tetapi masih berpedoman pada Undang-Undang Nomor 11 tahun 1992 tentang Dana Pensiun. Sementara ketentuan dalam UU Ketenagakerjaan tersebut dalam memberikan kompensasi PHK dengan perhitungan Upah dan dibayarkan secara tunai, disisi lain dalam UU Dana Pensiun pembayaran kompensasi PHK dengan perhitungan gaji pokok dan dibayarkan secara mencicil setiap bulan.

Bahwa dalam melaksanakan suatu kebijakan sering terjadi beberapa pilihan, harus diambil pada satu keputusan yang paling tepat dan benar, sehingga kadang-kadang disatu pihak akan memberikan kelebihan/keuntungan pihak tertentu, akan tetapi pada sisi lain akibatnya berpotensi menimbulkan kekurangan/kerugian pihak lainnya. Selanjutnya bahwa pelaksanaan kompensasi PHK yang dilakukan oleh manajemen PT PELNI, juga terdapat hal-hal yang mengandung beberapa kelebihan/keuntungan pada pihak tertentu, akan tetapi disisi lain sebaliknya menimbulkan kekurangan/kerugian pada pihak lainnya. Faktor utama dari permasalahan pelaksanaan kompensasi PHK PT PELNI adalah terlambatnya manajemen PT PELNI untuk mengambil kebijakan pemberian kompensasi PHK, dengan menyesuaikan ketentuan PHK, sebagaimana yang ditetapkan dalam ketentuan Undang-Undang No. 13 tahun 20013 tentang Ketenagakerjaan.

Kebijakan pelaksanaan kompensasi PHK yang dilakukan oleh PT PELNI terdapat kelebihan dsn kekurangan, Khususnya untuk pekerja yang bertugas pada 
golongan rendah, misalnya: pelayan, pengemudi, dan satpam atau staf yang berada pada posisi golongan I, II dan III yang tidak memiliki jabatan Manajerial, akan memperoleh keuntungan pada pelaksanaan PHK yang dilaksanakan PT PELNI. Dalam hal ini dengan pemberian pensiun yang dibayarkan perbulan dengan didasarkan atas gaji pokok terakhir adalah lebih menguntungkan (sebagaimana ketentuan Dana Pensiun PELNI) walaupun terjadi perbedaaan kekurangan relatif kecil, sedangkan perhitungan pembayaran kompensasi PHK berpedoman pada UU Ketangakerjaan menggunakan komponaen Upah sebulan terakhir. Apabila diperhatikan dalam komponen pembayaran penghasilan pekerja di PT PELNI akan terlihat bahwa perbedaan gaji pokok antar masing-masing golongan bagi pekerja tidak terpaut terlalu jauh, sedangkan perbandingan tunjangan penyesuaian dan insentif prestasi antar klas jabatan bagi pekerja sangat jauh perbedaannya. Sedangkan hal ini sangat merugikan khususnya pekerja yang menduduki jabatan setingkat Manajer dan Senior Manajer/General Manajer. Karena bisa dilihat dengan komponan upah yang tinggi (khususnya tunjangan penyesuaian dan insentif prestasi), sehingga apabila mengacu pada UU Ketenagakerjaan bahwa perhitungan kompensasi PHK dihitung berdasarkan seluruh komponen upah (sejumlah penghasilan tetap selama sebulan terakhir).

Demikian manajemen PT PELNI dalam melaksanakan kompensasi PHK kepada para pekerjanya, tidak memenuhi kriteria atas ketentuan sebagaimana yang telah ditetapkan pada Undang-Undang No. 13 tahun 2003 tentang Ketenagakerjaan, sehingga manajemen PT PELNI dapat dikategorikan tidak mematuhi hukum yang berlaku, sehingga mengakibatkan tidak terpenuhi hak-hak pekerja sebagaimana yang telah diatur dalam UU Ketenagakerjaan tersebut. Walaupun faktanya Manajemen PT PELNI mendirikan Yayasan Kesehatan Pensiun Pelni (YKPP) yayasan tersebut merupakan kepanjangan tangan dari Manajemen PT PELNI dalam memberikan jaminan pelayanan kesehatan terhadap para pensiunan pekerja PT PELNI selama hidup.

\section{PENUTUP}

A. Ketentuan pembayaran kompensasi pemutusan hubungan kerja (PHK) telah ditetapkan dalam Undang-Undang No. 13 tahun 2003 tentang Ketenagakerjaan secara rinci, walaupun ketentuan tersebut telah lahir 15 (lima belas) tahun yang 
lalu ternyata belum semua perusahaan melaksanakan kewajibannya sebagaimana ketentuan Undang-Undang Ketenagakerjaan tersebut. Salah satunya PT PELNI (Persero), walaupun disisi lain memberikan tambahan kompensasi pelayanan kesehatan selama hidup pada pekerja yang menjalani masa pensiun normal dan atau istri pekerja yang meninggal dunia.

B. Kebijakan Manajemen PT PELNI yang memberikan pembayaran kompensasi PHK dengan berpedoman pada UU No. 11 tahun 1992 tersebut merugikan pekerja PT PELNI, karena dalam perhitungan UU Dana Pensiun memperhitungkan PHK berdasarkan Gaji Pokok, sedangkan ketentuan UU Ketenagakerjaan perhitungan pembayaran kompensasi PHK berdasarkan Upah (Gaji pokok, ditambah semua tunjangan yang diterima sebulan). Hal ini berpotensi akan menimbulkan permasalahan hukum dikemudian hari, seharusnya segera dicari jalan keluarnya, sehingga tidak akan merugikan pekerja maupun PT. Pelni sendiri.

\section{DAFTAR PUSTAKA}

\section{Buku:}

Asyhadie, Zaeni, Hukum Ketenagakerjaan, Jakarta: Raja Grafindo Persada, 2008.

Dinsi, Valentino, Ketika Pensiun Tiba, Jakarta: LET'S GO Indonesia, 2006.

Husni, Lalu, Hukum Ketenagakerjaan, Jakarta: Raja Grafindo Persada, 2007.

Khakim, Abdul, Dasar-Dasar Hukum Ketanagakerjaan Indonesia, Bandung: Citra Aditya Bakti, 2009.

Marbun, Rocky, Jangan Mau Di PHK Begitu Saja, Jakarta: Visimedia, 2010.

Marwan. M. dan Jhimmy P., Kamus Hukum, Surabaya: Reality Publisher, 2009.

Sidabutar, Edy Sutrisno, Pedoman Penyelesaian PHK, Jakarta: Elpress, 2005.

Soepomo, Iman, Pengantar Hukum Perburuhan, Jakarta: Djambatan, 1987.

Sutedi, Adrian, Hukum Perburuhan, Jakarta: Sinar Grafika, 2009.

Wijayanti, Asri, Hukum Ketenagakerjaan Pasca Reformasi, Jakarta: Sinar Grafika, 2010. 


\section{Peraturan Perundang-Undangan:}

Himpunan Peraturan Perundang-Undangan Ketenagakerjaan, Jakarta: Kemenakertrans, 2011.

Peraturan Dana Pensiun PT. Pelni, Jakarta: Dapen Pelni, 2006.

Perjanjian Kerja Bersama Direksi dengan Serikat Pekerja PT. PELNI,

\section{Undang-Undang:}

Undang-Undang RI No. 11 Tahun 1992, Tentang Dana Pensiun, Media Internet, 2011.

Undang-Undang RI No. 13 Tahun 2003, Tentang Ketenagakerjaan, Jakarta: Disnakertrans DKI Jakarta, 2004.

UU-RI No. 21 tahun 2000, Tentang Seikat Pekerja/Serikat Buruh, Media Internet 22 Desember 2011.

\section{Lain-lain:}

Hikmah, Binaputra Jaga, Laporan Berkala AktuariaDana Pensiun Pelni Tahun 2010, Jakarta: Binaputra Jaga Hikmah, 2010.

SK Direksi Dana Pensiun Pelni No.14/Dir/MPD/VI-2011, Jakarta: DPP, 2011 